\title{
SPATIAL LOCATIONS OF MARGINALIZED COMMUNITIES IN INDIAN CITIES
}

\author{
Mohd Resaal Ansari \\ Department of Urban Design \\ School of Planning and Architecture Bhopal, \\ Bhopal, Madhya Pradesh, India
}

\begin{abstract}
Rapid urbanization and urban migration have led to people move to urban centers for better job opportunities. Due to lack of housing, infrastructure and incapability of purchasing of house in the formal housing sector some people are forced to live in inhabitable conditions such as in slums and squatters. These people due to their social status and living standards often face social exclusion resulting in marginalizing them, thus called 'marginalized communities'. The people of the marginalized communities locate themselves in cities based on various physical, socio-cultural and economic factors. The residential settlements of marginalized communities are majorly located on unused, underutilized or disputed land mainly government land; on inhabitable geographical locations; near social and religious infrastructures, and common cultural interest such as religion, ethnicity, occupation etc. The close vicinity of the work centers to the residential settlements, also play an important role. The case studies selected are analyzed for their spatial location in the cities based on the aforementioned factors, which could be used as a key factor while relocating and rehabilitating these marginalized communities.
\end{abstract}

Keywords - Marginalized Communities, Migration, Rehabilitation, Slums, Urbanization

\section{INTRODUCTION}

The world saw rapid urbanization due to the industrial revolution which was further catalyzed by the globalization. The result was the high rate of migration of people from the rural areas to the urban areas in search of better job opportunities, living conditions. However, the rate at which the infrastructure and other services are developed in the cities were not able to cope with the rate of urbanization, thus leading to a lag. Due to the lag in affordable housing, infrastructure, low wages a lot of migrants are forced to live in slums, squatters, temporary shelters and unauthorized colonies in inhabitable conditions in dense clusters, without proper infrastructure and services such as water supply, electricity, sanitation, health, education to name a few and still paying high rents. A lot of people have been living without their families and have to send money back home, thus facing economic crunch in the city which effects their living conditions. A lot of them who have been living in cities for years are deprived of identity proofs thus they feel lost in the city. These people face social exclusion in the cities due to their income and standard of living.

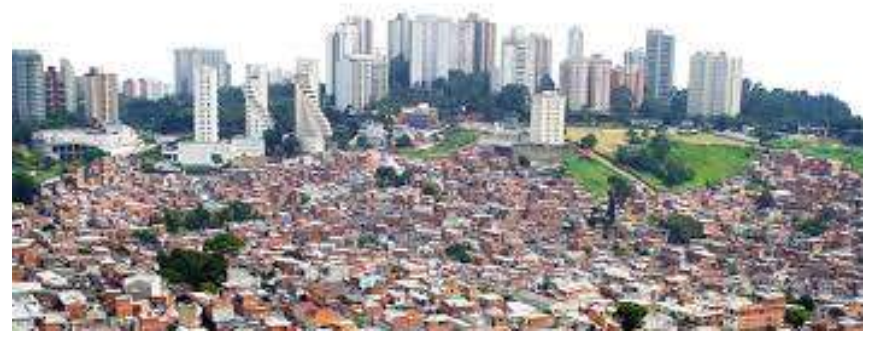

Figure 1 Formal and Informal Settlements in Cities Source: Cities Alliances: Cities Without Slums

These marginalized communities play a very important role in shaping the cities. They are the major workforce that would work in the formal sector. They would also be a part of the informal sectors and help the formal sector. These people work as taxi drivers, informal vendors, household helps, cart pullers, artisans, craftsmen and run small scale industries. These people act as the backbone of the cities they live and work in.
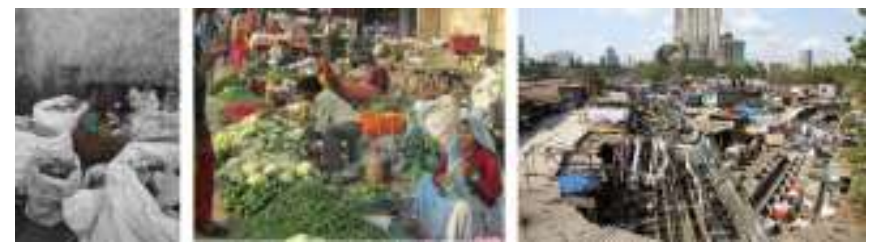

Figure 2 Marginalized Communities Source: Author; NASVI; REVITALIZATION- A Journal of Urban, Rural and Environmental Resilience

The marginalized communities locate themselves in slums, squatters based on various factors such as the place is near to their work centers, thus commuting to the work centers is cheap. These people majorly occupy land parcels owned by government, and/or are inaccessible, or are located near Nullahs, railway tracks, high speed corridors, dumping grounds etc. These marginalized communities also tend to locate themselves in places which are with or near by the 
people sharing the same community interests. These might be based on social status, religion, ethnicity, occupation etc. These people also try to locate themselves in places which have schools, hospitals, water supply, market in their vicinity.

\section{HYPOTHESIS}

The research focuses on exploring the various parameters and factors that the marginalized communities use to orient or locate themselves in cities.

The hypothesis framed is "the marginalized communities adopt some parameters to locate their residential settlements in the cities."

\section{OBJECTIVES}

- To study the role of marginalized communities in cities

- To study the concentration pattern of marginalized communities in cities

- To study the prime factors responsible for location of marginalized communities in cities

\section{SCOPE OF WORK}

The research focuses mainly on understanding the factors that the marginalized communities use to locate themselves in cities, which could be used as a key point to relocate and rehabilitate these groups as part of slum redevelopment projects.

\section{LIMITATIONS}

The study deals with the spatial location of marginalized communities and the responsible factors. It does not deal with the built form, living conditions and the size of the marginalized communities.

\section{METHODOLOGY}

The methodology adopted to conduct the research for the spatial location of the marginalized communities in Indian cities involves

- Selection of study area: Selecting a city which has seen significant urban migration from rural to urban areas in search of jobs, and has seen a significant number of people to be marginalized on the basis of jobs, living conditions and standards, ethnicity, culture etc.

- Spatial location of settlements: Looking at the physical locations of the settlements, slums and squatters, of the marginalized communities across the selected city of study.

- Identifying the factors for locational preference: Based on the literature study conducted identifying the factors that the marginalized communities have used to establish their settlements in the cities and the newer migrants belonging to these communities use to locate or orient themselves in the city.

- Identifying key marginalized communities: It involves identifying the key marginalized communities which could be relatable to the identified factors of locational preferences of these marginalized communities.
- Analysis: Analyzing the selected marginalized communities with the selected factors.

- Findings and Conclusions: Findings from analysis of the case studies on the different factors could be used as parameters while relocating, rehabilitating the marginalized groups.

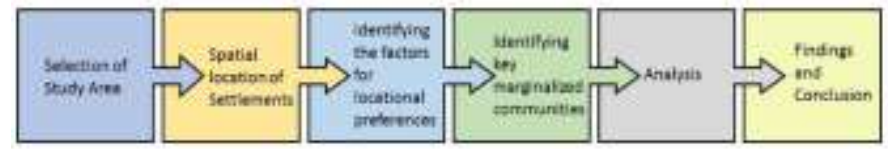

Figure 3 Methodology Source: Author

\section{LITERATURE REVIEW}

\section{A. Marginalized Communities -}

Marginalized communities are defined as the people within a given culture, context and history at risk of being subjected to multiple discrimination due to the interplay of different personal characteristics or grounds, such as sex, gender, age, ethnicity, religion or belief, health status, disability, sexual orientation, gender identity, education or income, or living in various geographic localities.

Belonging to such groups or even being perceived to belong to them heightens the risk of inequalities in terms of access to rights and use of services and goods in a variety of domains, such as access to education, employment, health, social and housing assistance, protection against domestic or institutional violence, and justice. "EIGE et al. 2018"

\section{B. Formation and morphology of settlements of marginalized communities -}

The settlements of marginalized communities are in the form of slums, squatters, unauthorized colonies which were formed due to the rapid urbanization and migration of people from rural areas to urban centers in search of job opportunities. Due to housing shortage and incapability of these people to purchase house in the formal housing sector these people started living in such informal settlements. In the initial stage slums and squatter settlements came up near the work centers such as dockyards and factories, during the industrial revolution. In the initial stage these settlements were on the periphery of the cities which eventually became a part of the city center, when the cities expanded, thus formal and informal settlements became an integral part of the urban sprawls.

The formation and growth of these settlements are also a result of poor housing planning; colonialism and segregation; poor infrastructure, social exclusion and economic stagnation; informal economy; poverty; politics; social conflicts; natural disasters "Ooi et al. 2007". Poor urban governance and illdesigned policies have also resulted in the sustenance and growth of these settlements "Ron Mahabir et al. 2016".

These settlements grow in size both horizontally or vertically on the availability of open land. People having been born and having close association with their settlements tend to move 
out near a settlement in close proximity of these settlements, thus growing the settlement at a new center.

\section{Role of Marginalized Communities in Shaping Cities -}

The marginalized communities play a very important role in shaping the cities. They are the major workforce in the formal sector. They would also be a part of the informal sectors such as small scale and cottage industries which would help the formal sector as ancillary units. These people work as taxi drivers, informal vendors, household helps, cart pullers, artisans, craftsmen, sweepers, sewage cleaners and taking class IV jobs, thus acting as the backbone of the cities, making the cities better place for the higher societies, even though they are socially excluded.

\section{Spatial Concentrations of Marginalized Communities -}

The settlements of the marginalized communities are concentrated majorly near the periphery of the cities near some natural water resource such as river, lake, drainage etc. Within the cities these settlements are concentrated near the work centers; markets for their goods; socio-cultural centers and infrastructure; near water bodies, challenging land forms and unused, underutilized and disputed land mainly government lands.

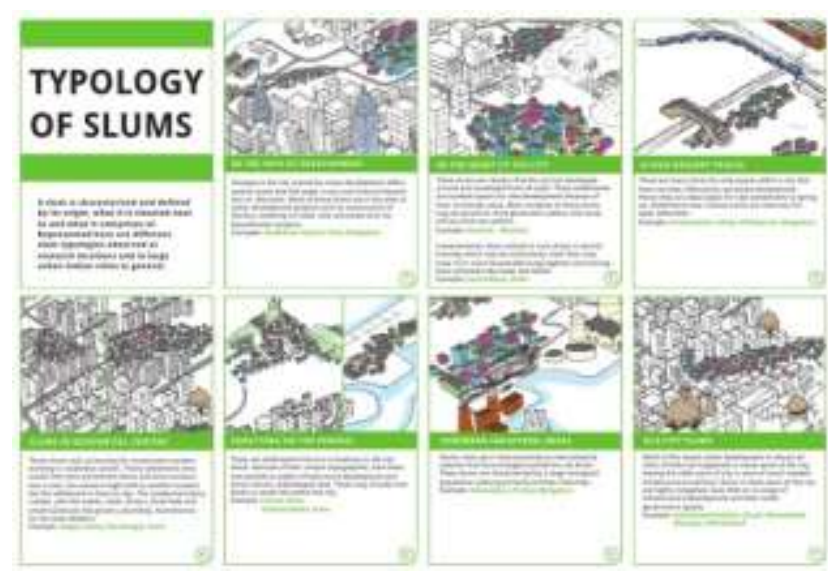

Figure 4 Typology of Slums Source: The Potty Project



Figure 5 Spatial Location of Slums in cities Source: The Potty Project

\section{E. Locational choice factors -}

The marginalized communities locate themselves in the city on various physical, socio-cultural and economic factors.

Physical factors: The physical setting plays a very important factor in deciding the location of the informal settlements. Due to the lack of sufficient housing, high prices of the land and the incapability of the marginalized groups to buy housing in the formal housing, due to low income, the marginalized construct houses on locations which are challenging or inaccessible for construction. The most favorable land for informal settlements is the land owned by the government, unused, underutilized and/or disputed lands. Several geographical features also play an important location for construction. The land near water bodies such as rivers, nullahs, swamps, railway lines, dumping grounds, high speed corridors are more preferable locations.
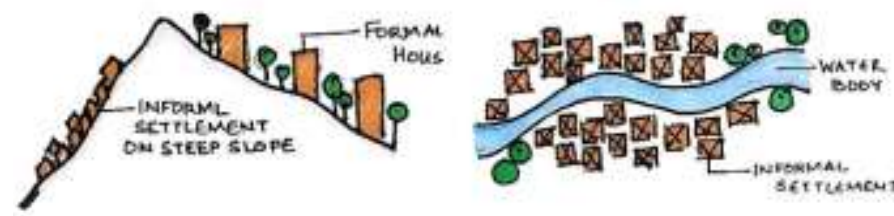

Figure 6 Physical Locational Choices of Slums Source: Author

In mountains the steep slopes which are not fit for construction or at the bottom of flood prone valleys often close to some natural water body and hidden from the view of the city center are used by these marginalized groups to construct their slums and squatters. for example, Rio de Janeiro in Brazil and Lima in Peru, are notoriously known for building on steep slopes. Such locations are usually unsafe, posing a risk to human life because of the occurrence of natural disasters such as landslides "Ron Mahabir et al. 2016". In cities situated near lagoons, marshy land, rivers the construction starts at the bank or on stilts or on dry river bed.

Socio-cultural factors: The marginalized groups also keep in the social and cultural infrastructures in mind while deciding upon the location for their settlements. Their settlements are located at places which are in close proximity with educational and health facilities, market places, transportation and easy availability of infrastructure such as electricity, water supply, although illegal.

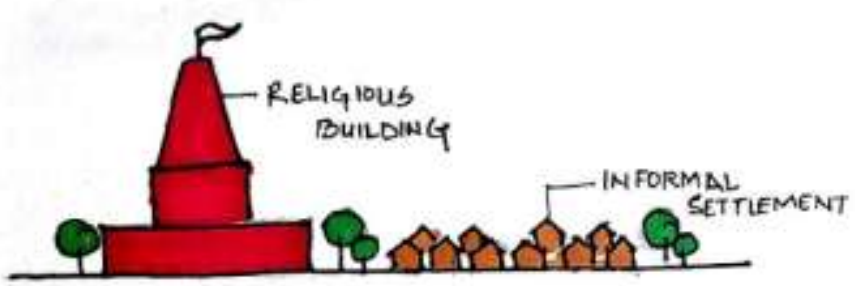

Figure 7 Socio-Cultural Locational Choices Source: Author 


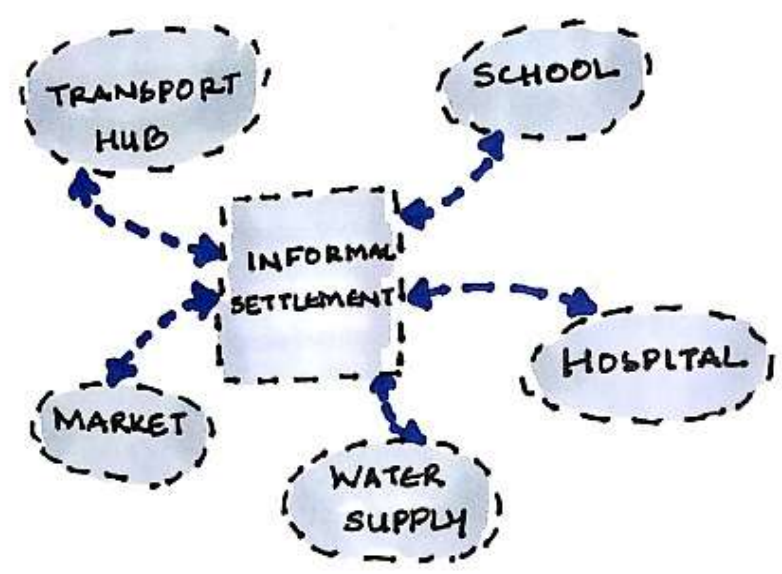

Figure 8 Relation with Socio-Cultural infrastructure Source: Author

Religious precincts such as temples, mosques, dargahs are also preferred location for these groups for example the Nizamuddin basti in New Delhi is location in the vicinity of the Hazrat Nizamuddin Dargah. New migrants of these marginalized groups also like to locate themselves with people sharing common socio-cultural interests such as ethnicity, religion, language, social status, occupation, housing quality, neighborhood amenities. For example, a Bengali speaking migrant would orient himself in locations where there are Bengalis rather than any other community. Similarly, a migrant who is potter by profession would choose a location where there are significant potters as it will also give him a market for his goods in the vicinity. A migrant who could purchase a semi-pukka or pukka house would not live in a settlement constructed out of temporary materials such as corrugated sheets or mud etc. It has also been found that people born within or in close proximity to slums tend to remain in them or move to them, while some slum dwellers are of the belief that places outside of slums are out of their reach. This suggests that any efforts to address the issue of slums must also consider their surroundings and their social structures. "Ron Mahabir et al. 2016"

Economic Factors: Economic factors plays an important role in deciding the location of the settlements of these people. During the industrialization period, people moved from rural areas to urban areas in search of jobs in various factories and industries. To save commuting time and cost and no provision of housing by the employers, people started to settle near these factories in the form of slums and squatters.

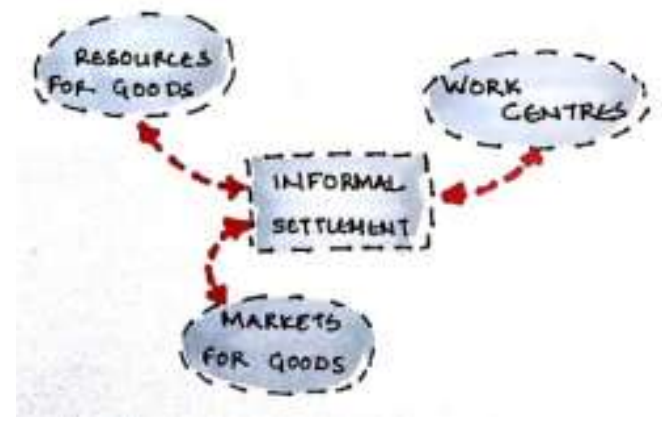

Figure 9 Live-Work Relationship Source: Author In the present situation people also adopt the same way for settlements as they would settle near their work centres for saving commuting cost and time. For example, household helps living in a particular slum, whose work centres and in the nearby neighborhoods. A lot of small scale and cottage industries came up in these settlements which acted as ancillary units for the formal industries thus these settlements always locate themselves near a factory. Communities performing a common occupation would live and work together with markets for their goods and services in the nearby locations and also the availability of the resources for their goods in the vicinity. For example, a dhobi community would want to locate themselves where they could have easy access to water bodies for washing clothes and open spaces for drying.

However, these factors could not be looked into isolation. There is always a combination of these factors and individual choices while deciding upon the location of the residential settlements by these marginalized communities.

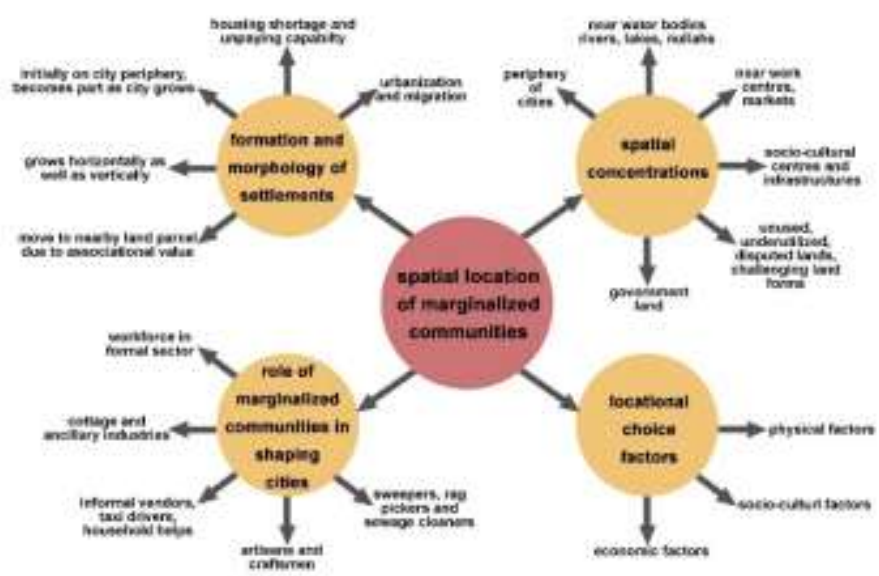

Figure 10 Literature Mind Map Source: Author

\section{FORMULATION OF FRAMEWORK FOR ANALYSIS OF CASE STUDIES}

The literature case study focuses on finding the ways in which the people of the marginalized communities have located their residential settlements across the cities and the newer migrants locate and orient themselves in these settlements and the city. The factors that leads to the locational preferences of the 
marginalized communities for their residential settlements, these factors can be broadly categorized as

1. Physical Factors: the geographical locations, land ownership

2. Socio-cultural Factors: the socio-cultural background and interests of the people and the availability of sociocultural infrastructure and services

3. Economic Factors: the location of work centres, commuting cost and time, availability of goods markets and resources for their goods.

Further with the help of these factors as parameters the locations are to be analyzed as up to what quantum these parameters are used by the marginalized communities for the spatial location of their residential settlements.

\section{ReleVANCE OF CASE STUdies}

Dharavi is the biggest slum in Asia in the economic capital of India, Mumbai, thus Dharavi has seen a lot of people migrating from various parts of the country. It used to lie on the periphery of the city which eventually became a part of the city as it grew. The population of Dharavi consists of people from diverse socio-cultural background, practicing various occupations. The physical setting of Dharavi is also according to the physical factor of locational choice factors of slums and squatters.

Shanti Nagar in M.P. Nagar, Bhopal houses people from the rag picking community. And as people from sweeping, sewage cleaning and rag picking communities as the most down trodden and marginalized in cities, thus taking them as case study was relevant. Their work centers are near them, and the squatter lies on government land on the bank of a nullah.

Vishwakarma Nagar in Habibganj, Bhopal lies on a disputed land along a high-speed corridor, near a transit hub and below the road level. It in-houses people from two different communities i.e. Bengalis and Biharis, thus taking this as a case study to see how people from different ethnical backgrounds locate themselves in the same community. Also, people have different works centers, thus looking at the different economical factor that has led to locate themselves in this area.

\section{Literature CASE StUdy}

\section{A. Dharavi, Mumbai}

Dharavi in Mumbai is the largest slum in Asia spread over an area of 239 hectares and an estimated population of 700,000 people particularly migrants from all across the country such as Uttar Pradesh, Bihar, Bengal, Karnataka and significantly from Tamil Nadu and Maharashtra. Over decades the site has been dramatically transformed and its development consolidated, layering generations of slum dwellers in what are now 85 nagars (neighborhoods), organized in a complex labyrinthic physical layout, built around multifunctional worklive dwelling forms.

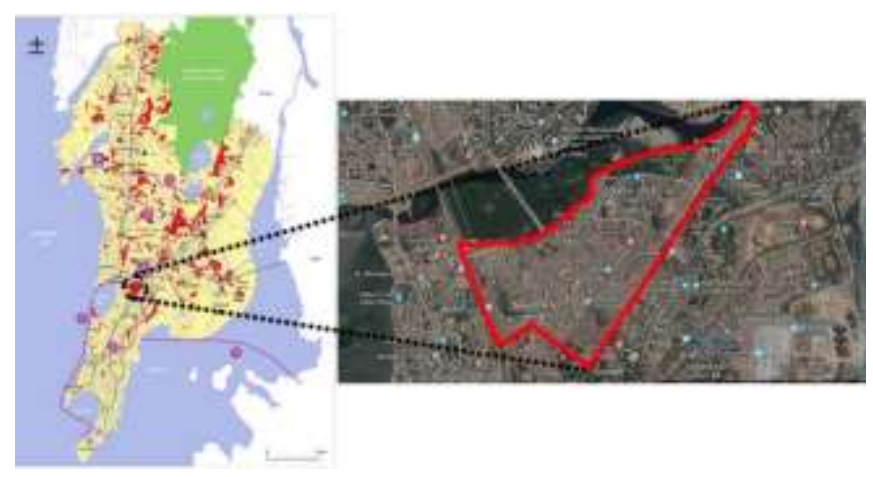

Figure 11 Mumbai Slum Map and Map of Dharavi Source: MMRDA

Physical Factors: Dharavi is a large area situated between Mumbai's two main suburban railway lines, the Western and Central Railways. To the west of Dharavi are Mahim and Bandra, and to the north lies the Mithi River. Historically evolving from a small fishing village, Dharavi became the city's geographical center, as Mumbai's urban development and corresponding squatter settlements were pushed northwards, off valuable land in South Mumbai onto its current swampy, unhygienic location. From this once marginalized, neglected area Dharavi is now strategically located between inner-city districts and Mumbai's new financial center called the Bandra-Kurla Complex, near the Chhatrapati Shivaji International Airport. "Boano et al. 2013"

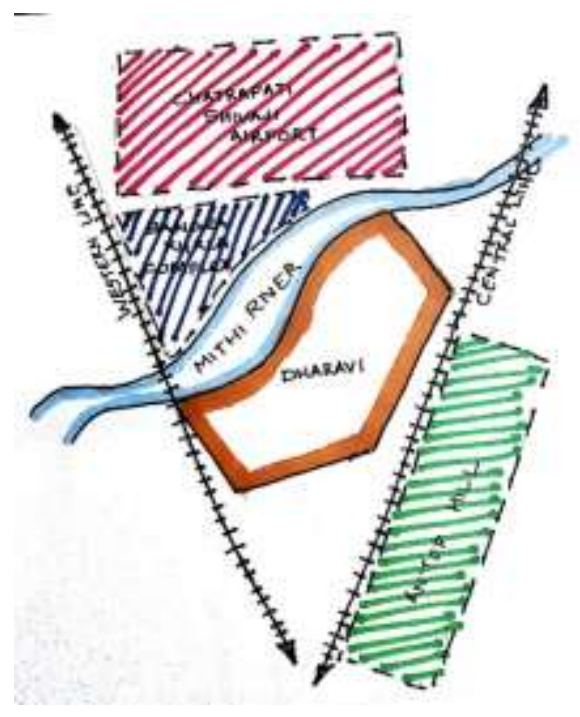

Figure 12 Physical Setting of Dharavi Source: Author

Socio-cultural Factors: Dharavi has seen a lot of migrants from different part of the country viz. Uttar Pradesh, Bihar, Bengal, Karnataka and significantly from Tamil Nadu and Maharashtra. They are also people belonging to different religions and caste such as Muslims, Hindus, Adi Dravidas, Nadars, Thevars, Konchikoris to name a few who reside in their respective neighborhoods out of the 85 nagars (neighborhoods) in Dharavi. Dharavi has all the major sociocultural infrastructures such as schools, medical facilities, colleges etc. close proximity. 
Economic Factors: Dharavi is the hub for small scale industries such as leather industry, waste recycling industries, wax printing, aluminium brick making industries, pottery making industries distributed spatially in various neighborhoods around Dharavi. "Mahawar et al. 2015". These industries have work places along with residential units. They also have ancillary textile industries which would support the textile mills in the city. The women in the slum would work as house hold helps in the high-class societies and commute using the local trains, which is an affordable mode of transport. Some people also work as informal vendors in the close proximity of their settlements such as vegetable vendors, panipuri walas etc.

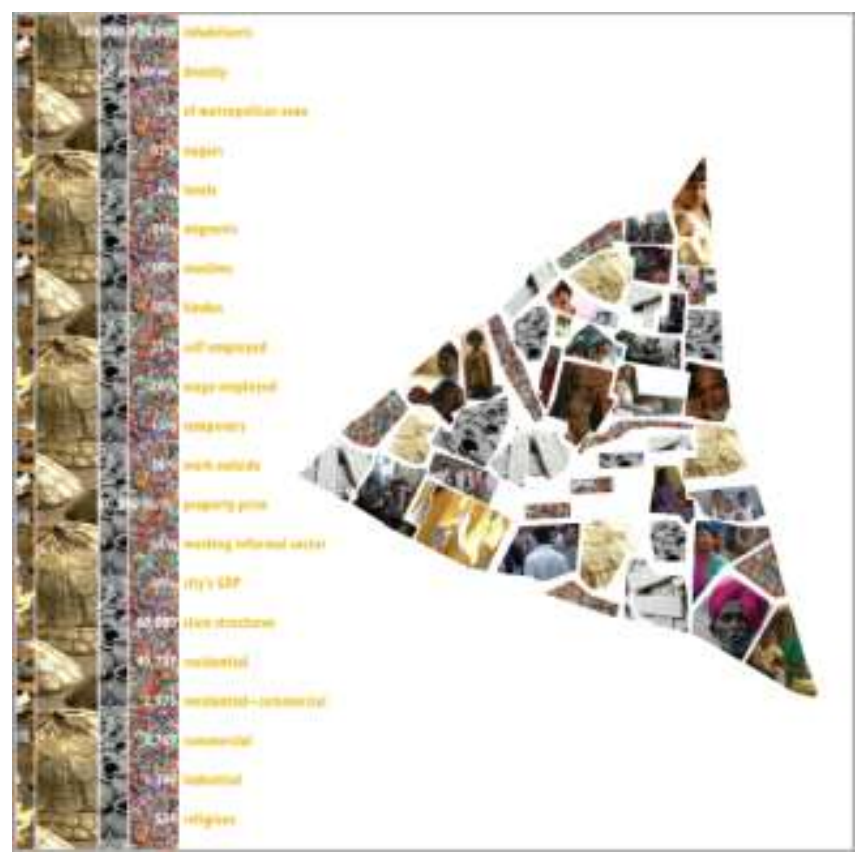

Figure 13 Conceptual Socio-Cultural and Economic Layout of Dharavi Source: Contested Urbanism in Dharavi

\section{PRIMARY CASE STUdy}

\section{Introduction and Overview of the City: Bhopal}

The primary case study was conducted in various locations in Bhopal city. The city has almost 1000 years of history starting from the times of Raja Bhoj who established the city and constructed upper lake. City was ruled by various rulers and city has evolved with time accommodating the necessities of various time periods. The historical city has an inner core with an urban structure dates back to $1000 \mathrm{AD}$ and the surrounding urban fabric with walls, gateways and magnificent religious structure comprises the old core of city.

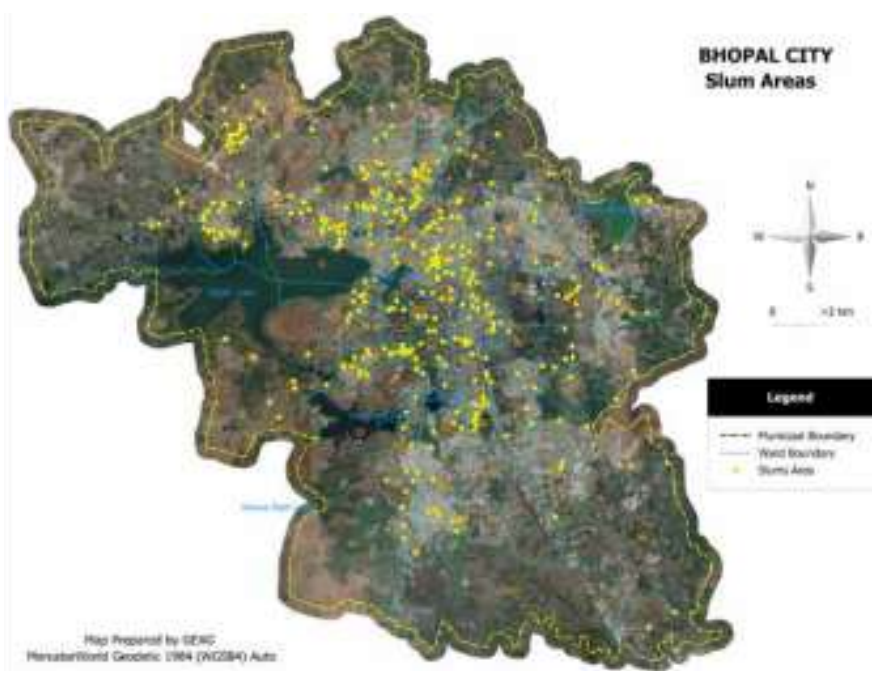

Figure 14 Slum Map of Bhopal City Source: Bhopal Municipal Corporation

After becoming the capital city of Madhya Pradesh after independence, Bhopal has seen a significant urban migration from various parts of the country such as Maharashtra, Bengal, Bihar, other parts of Madhya Pradesh and even across the border, the Sindhi community migrated from Pakistan to Bhopal and settled in Bairagarh area of the city, which lies on the periphery of the city. A large number of slums, squatters have been seen spread all across the city concentrating on government lands, along the lake edge and Nullahs, dumping grounds and other locations, out of which two settlements i.e. Shanti Nagar and Vishwakarma Nagar which have significant marginalized based on the aforementioned factors.



Figure 15 Location of Selected Study Areas Source: Urban Design Studio, M. Arch II year, SPA Bhopal

\section{A. Shanti Nagar, M.P. Nagar}

Shanti Nagar is a squatter settlement lying in the southern part of M.P. Nagar, a commercial hub of the city. The squatter comprises of around 50-60 families comprising majorly of rag pickers migrated from Maharashtra and other parts of Madhya Pradesh. The settlement started around 40 years ago with 1015 families and eventually expanded to the present condition. 


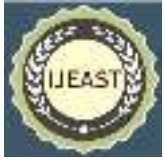



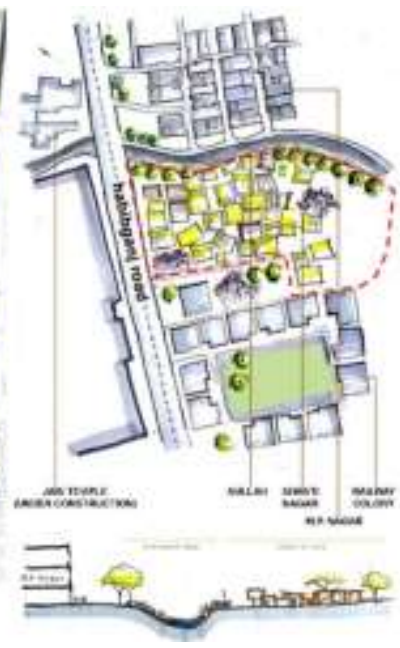

Figure 16 Location of Shanti Nagar and its Physical Setting Source: Collaborative Studio with SPA Delhi; KRIVIA, Mumbai; NTNU, Norway; SPA Bhopal at SPA Bhopal

Physical Factors: The site is located on the southern part of the M.P. Nagar on the government land near the government water pump beside a Nullah. The settlement also lies along the Habibganj Road, which is a high-speed corridor. The settlement came up on the periphery of the city which became a part of the city when M.P. Nagar was developed as the new CBD of Bhopal.

Socio-Cultural Factors: The people living in shanti nagar majorly belong to the same socio-cultural background practicing majorly as rag pickers, drivers in BMC, household helps and same social status living in temporary structures made up of corrugated sheets, plastics. They also have various facilities and services in close proximity such as Habibganj market, Bittan market, Sanjay Gandhi school and Aanganwadis, Jai Prakash Hospital. They also have easy access to the BRTS of the city to commute to other places.

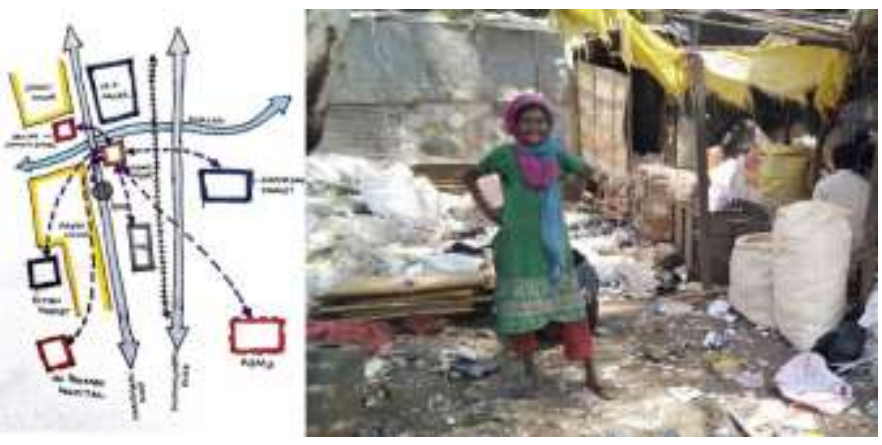

Figure 17 Relationship of Shanti Nagar with Socio-Cultural Infrastructure and Their Occupation Source: Author

Economic Factors: Most of the people belong to the same occupation i.e. rag picking and waste segregation, which they do it in the squatter. They majorly go to rag picking to M.P. Nagar which is at walking distance from their houses. However, to sell their segregated waste they have to travel to dumping site near Bhopal Talkies. Some women in the settlement also works as house hold helps in the nearby neighborhood such as Arera Colony, Shivaji Nagar which are in close proximity to them.

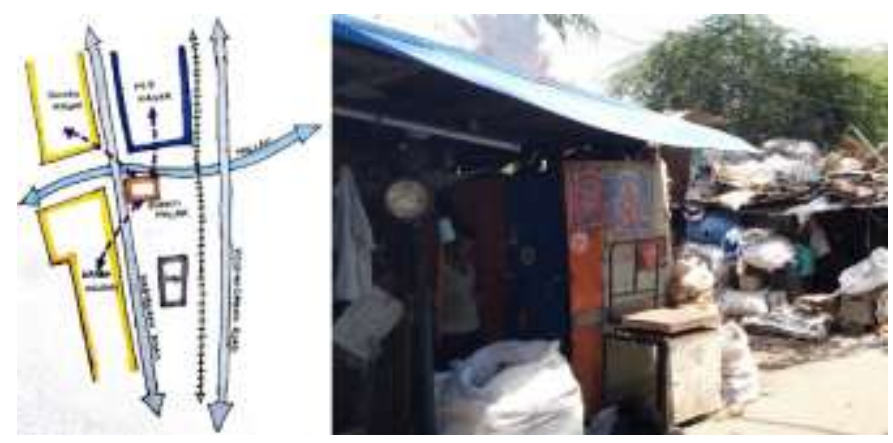

Figure 18 Live-Work Relation of The Community and their Work Centers Source: Author

\section{B. Vishwakarma Nagar, Habibganj}

Vishwakarma Nagar slum is located in front on the east end (Platform 5) of the Habibganj Railway station on Hoshangabad road connecting ISBT in the north and Mandideep in the south. The slum started nearly 45 to 50 years ago comprising of migrants from Bengal and Bihar who live in different parts of the slum which is clearly reflected in their physical planning, as the Bengali community has more open spaces between their clusters while the Bihari community has very narrow lanes and rare open spaces.
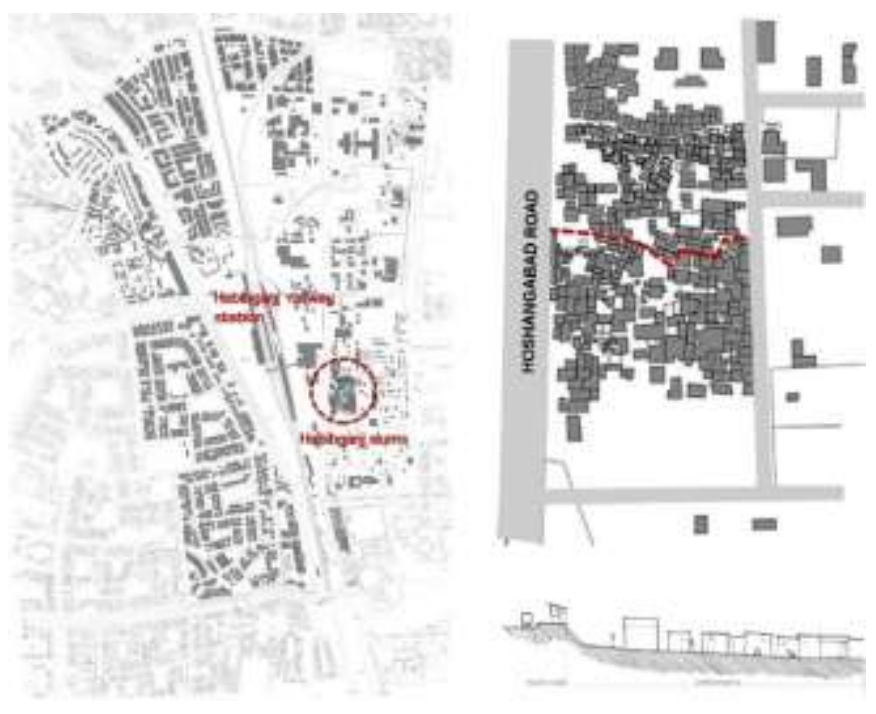

Figure 19 Location of Vishwakarma Nagar Source: Collaborative Studio with SPA Delhi; KRIVIA, Mumbai; NTNU, Norway; SPA Bhopal at SPA Bhopal

Physical Factors: The slum is located in front of the east end (Platform 5) of the Habibganj railway station significantly below the road level, thus cutting their visibility to some extent. The slum is located on a disputed land, between the railway authorities and BHEL industry. The slum is located on Hoshangabad road, which was a highway and now a highspeed corridor within city limits. 


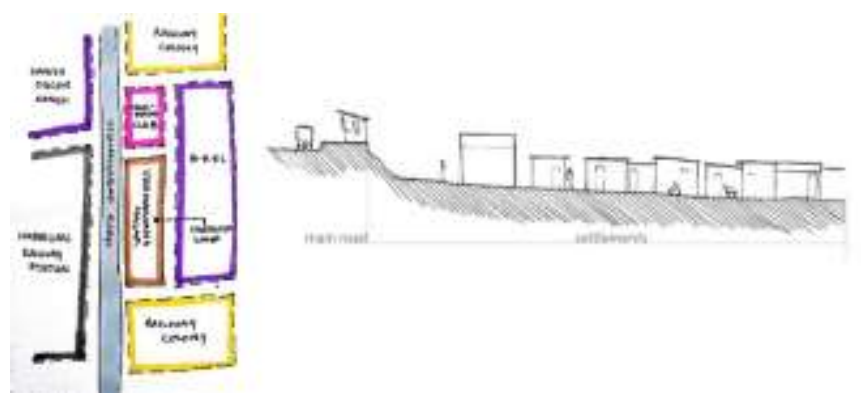

Figure 20 Physical Setting of Vishwakarma Nagar Source: Author and Collaborative Studio with SPA Delhi; KRIVIA, Mumbai; NTNU, Norway; SPA Bhopal at SPA Bhopal

Socio-cultural Factors: The people of Vishwakarma Nagar below to two different ethnic groups i.e. Bengalis and Biharis which is clear from their physical planning and their social spaces, as the Bengalis have more open spaces between their clusters and have kaali Baadi next to their cluster which Biharis have much dense cluster with narrow alleys. Although no dispute between the communities there is still clear cultural segregation between them. They also have various facilities and services in close proximity such as Habibganj market, Bittan market, Sanjay Gandhi school and Aanganwadis, Jai Prakash Hospital. They also have easy access to the BRTS of the city to commute to other places.

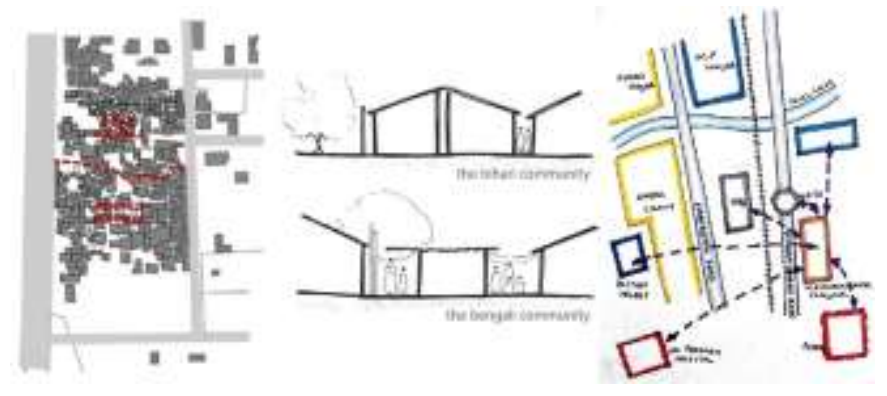

Figure 21 Social Distinction Between Different Communities of Vishwakarma Nagar and Their Relation with Social Infrastructure Source: Author and Collaborative Studio with SPA Delhi; KRIVIA, Mumbai; NTNU, Norway; SPA Bhopal at SPA Bhopal

Economic Factors: The people of Vishwakarma Nagar work as workers in various shops in M.P. Nagar, Old City. Some of them work as informal vendors in the near locality. The women work as house hold helps in the nearby neighborhoods such as Arera Colony, Shivaji Nagar etc. which are in close proximity.

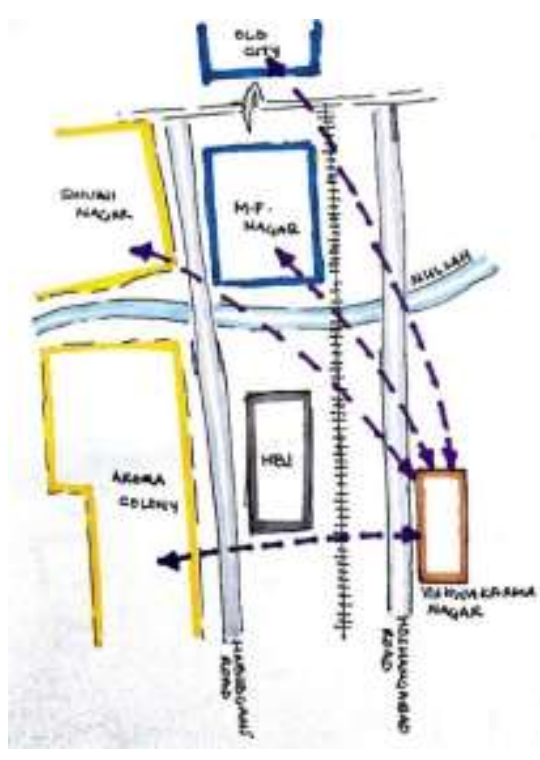

Figure 22 Live-Work Relationship of Vishwakarma Nagar with Their Work Centers Source: Author

\section{FINDINGS FROM CASE STUdIES}

On analyzing the case studies using the locational preference factors as parameters to decide the spatial location of the residential settlements by the marginalized communities, we found out that the locational preference factors such as the physical, socio-cultural and economic factors plays an important role in deciding the spatial locations of the settlements. The newer migrants also use these parameters to decide their potential location and orientation in the cities. For the newer migrants, cost of the land and cheap rents also play a vital role. Of All the above factors, physical factors, including the geographical locations, land ownership, are of their first priority as these lands are easily and cheaply available to them. Proximity to the work centers and infrastructures such as hospitals, schools, water supply are also an important aspect in this selection process.

The people living in these settlements have significant association to their settlements and are unwilling to be relocated somewhere else. Although if relocation is done, they need to be relocated to some place which is closer to their work centers and better infrastructure is provided to them. They also need valid identity proofs which would give them access to various benefits, facilities and services and giving them certain identity and rights to the city they live in.

\section{CONCLUSION}

The study established that the factors such as poor housing planning; colonialism and segregation; poor infrastructure, social exclusion and economic stagnation; informal economy; poverty; politics; social conflicts; natural disasters leads to the formation and growth of settlements like slums, squatters etc. Although the people living in these settlements, the marginalized communities, play an important role in shaping the city yet they are socially excluded and deprived of identity and rights in the city, thus are force to live in such settlements. 
The study also established that the locational preference factors such as the physical, socio-cultural, and economic factors play an important role while deciding the location of their settlements in the city. Also, it helps the newer migrant to orient and locate themselves in the city.

As there are lot of slum rehabilitation projects are going around the country, these factors may be used as parameters to decide the new land parcel for relocation and rehabilitation of these people, so that they are not out of proximity to their work centers, various services and infrastructure. In case of insitu rehabilitation their social and cultural backgrounds and interests should not be lost as they have associational value with their settlements and give certain rights and identity to them within the city.

\section{REFERENCES}

\section{Journal Article}

Boano, C. (2013). Contested Uranism in Dharavi. London: The Bartlett | Development Planning Unit.

KING, K. D. (2011). Forms of Informality: Morphology and Visibility of Informal Settlements. Alexandrine Press.

Mahawar, H. K. (2015). A visit to Dharavi. Research Gate.

Ooi, G. L. (2007). Urbanization and Slum Formation. J Urban Health.

Programme, U. N. (2003). THE CHALLENGE OF SLUMS: GLOBAL REPORT ON HUMAN SETTLEMENTS 2003. Earthscan Publications Ltd.

Ron Mahabir, A. C. (2016). The study of slums as social and physical constructs : challenges and emerging research opportunities. Regional Studies, Regional Science, 22.

Tomlinson, K. D. (2012). Dharavi: Informal Settlements and Slum Upgrading. Melbourne: Melbourne School of Design, University of Melbourne.

Winchester, H. P. (1988). The Location of Marginalised Groups in the Inner City. SAGE Journals.

Interview

Residents of Shanti Nagar, M.P. Nagar and Vishwakarma Nagar, Habibganj, Bhopal (September, 2018)

World Wide Web Address

EIGE. (2018, November 23). European Institute of Gender Equality.

Retrieved from https://eige.europa.eu/rdc/thesaurus/terms/1280 